\title{
EVALUATION OF INSPECTED VEHICLES IN REPORTING PERIOD AT TECHNICAL INSPECTION AND EMISSION CONTROL STATION
}

\author{
Jozef ŠVEC, Jaroslav DUREC, Jozef CHRASTINA, Juraj TULÍK \\ Slovak University of Agriculture in Nitra, Slovakia
}

\begin{abstract}
Technical inspection is a fast, relatively timely and inexpensive, and particularly comprehensive assessment of the technical condition of vehicles. The technical review process includes a wide range of control actions, which are slightly different depending on the category of vehicle. The evaluation of technical inspection is mainly dependent on the type of failures that occur on a vehicle, and it is a three-graded classification by the grades A, B or C. Based on data obtained from technical inspections, it is possible to determine the current condition of the fleet of road vehicles in the Slovak Republic.
\end{abstract}

Keywords: vehicles, technical inspection, results of technical inspections

At a time when the business and social environment develop dynamically, we can hardly imagine life around us without cars (Szabó et al., 2012).

To ensure a proper operating condition of vehicles and their operational reliability, especially ecology and safety, it is necessary to introduce a kind of a control mechanism that will ensure a comprehensive monitoring of the proper technical condition of vehicles in operation. This control mechanism must be particularly comprehensive, timely and inexpensive. All of these conditions of the control mechanism are met by 'technical inspection'. Technical inspection represents a set of checking actions to inform citizens about the technical condition of their inspected vehicles. This information is not only for that one particular citizen but is also very important for insuring vehicles, pricing, etc.

Part of technical inspection is also emission control. The main disadvantage of combustion engines is a combustion product - emission (Müllerová et al., 2012). Traffic is a problem, especially in cities with high levels of pollution from exhaust gases $\left(\mathrm{CO}, \mathrm{HC}, \mathrm{NO}_{x^{\prime}}, \mathrm{PM}\right)$ and in places where most of the population lives (Štefina et al., 2012). The vehicles that passed the technical inspection meet the emission limits prescribed by the manufacturer or set forth by generally binding regulations, and are environmentally friendly, without increased exhalations. Results obtained in such an inspection can also be used to determine the quality and structure of the vehicle fleet, failure probability, or the precision of technical performance of vehicles of all categories that are subject to roadworthiness tests.

\section{Material and methods}

Diesel emission control is performed using the steps and procedures in the methodical guidelines for carrying out a regular emission control, emission control and administrative control published by the Ministry of Transport, Construction and Regional Development of the Slovak Republic (Králik et al., 2012).

The object of the analysis is to evaluate the roadworthiness of vehicles in the regular technical inspection of vehicles of $M_{2}, M_{3}$ and $N_{2}, N_{3}$ categories. During the selected period, there was analysed the number of vehicles submitted to technical inspection, together with their final evaluation. The final evaluation of vehicles is described by percentages from the total number of vehicles. Partial data are then compared, and results obtained are presented in graphs. For the reporting period, it is necessary to select such a time in which vehicles undergo the roadworthiness test (depending on the category), at least two times one after another. If the vehicle analysis for the reporting period is used for concluding the current condition of the vehicle fleet, the last calendar year of the reporting period must not be older than two years from the calendar year in which the analysis is performed. For a better comparison, the reporting period can be divided into equal time periods that make up one calendar year.

According to the Decree No 578/2006, vehicles are subject to regular inspection at different intervals according to individual categories. According to each vehicle category selected by us, the intervals are as follows:

a) $M_{1}$ and $N_{1}$ category: within four years after the first registration and thereafter periodically in two-year periods;

b) $M_{2}, N_{2}, M_{3}, N_{3}$ category: within one year after the first registration and thereafter periodically in one-year periods;

c) $M_{3}$ category: periodically in one-year periods after the first registration; periodically in half-year periods after eight years from the first registration;

c) $\mathrm{M}$ and $\mathrm{N}$ category used for ambulances, mine rescue and emergency service of gas equipment, vehicles used for taxi and vehicles used in driving school as a training vehicle: within one year after the first registration and then periodically in one-year periods.

In technical inspection, evaluated vehicles are classified into the groups A, B and C, and each of the classification grades represents a different vehicle condition, depending on failures detected on the vehicle.

The classification grade $A$ represents technical condition with no failures or with a minor failure that does not affect the safe operation of a vehicle on roads, and the vehicle is 
evaluated as qualified for road traffic. In such an evaluation, the vehicle is assigned a certificate of technical inspection, and the validity period of technical inspection is 24 or 12 months.

The classification grade $B$ means vehicle condition with a severe failure that affects the safe operation of the vehicle, but does not directly threaten the operated vehicle in road traffic. The vehicle is evaluated as qualified for temporary road traffic. The validity period of technical inspection is only 30 days. The document certifying the inspection performance is only the record on vehicle technical condition.

The classification grade $C$ is technical condition with at least one dangerous failure that affects the safety of operated vehicle and directly threatens its operation in road traffic, the safety of persons and property, the environment, or damages communications. The vehicle is not qualified for road traffic, there is no validity period of technical inspection, and the vehicle's operator or driver is required to have such a vehicle towed at their own expense from the inspection station.

The proportion of vehicles in individual evaluations is calculated by Equation (1) (Hrubec, 2001) and rounded to two decimal places.

$$
X=\frac{X_{1}}{N} \cdot 100
$$

where:

$X_{i} \quad$ - value of the variable $X$ of the $i$-th unit, pcs

$i \quad$ - file unit name ( $i=$ qualified, unqualified ...), pcs

$N$ - file size, pcs (Hrubec, 2001)

\section{Results and discussion}

Tables 1 and 2 contain the data obtained from technical inspection stations for the $\mathrm{M}_{2}, \mathrm{M}_{3}$ and $\mathrm{N}_{2}, \mathrm{~N}_{3}$ categories and for the selected reporting period.

Table 1 Evaluation of results according to vehicle categories in 2011

\begin{tabular}{|l||c|c|c|c|}
\hline Category & $\begin{array}{c}\text { Qualified } \\
\text { in pcs }\end{array}$ & $\begin{array}{c}\text { Temporarily } \\
\text { qualified in pcs }\end{array}$ & $\begin{array}{c}\text { Unqualified } \\
\text { in pcs }\end{array}$ & $\begin{array}{c}\text { Sum in } \\
\text { pcs }\end{array}$ \\
\hline \hline$M_{2}$ & 695 & 18 & 30 & 743 \\
\hline$M_{3}$ & 12,195 & 609 & 2,031 & 14,835 \\
\hline$N_{2}$ & 25,387 & 402 & 1,627 & 27,416 \\
\hline$N_{3}$ & 47,868 & 562 & 2,335 & 50,765 \\
\hline
\end{tabular}

Table 2 Evaluation of results according to vehicle categories in 2012

\begin{tabular}{|l||c|c|c|c|}
\hline Category & $\begin{array}{c}\text { Qualified } \\
\text { in pcs }\end{array}$ & $\begin{array}{c}\text { Temporarily } \\
\text { qualified in pcs }\end{array}$ & $\begin{array}{c}\text { Unqualified } \\
\text { in pcs }\end{array}$ & $\begin{array}{c}\text { Sum in } \\
\text { pcs }\end{array}$ \\
\hline \hline $\mathrm{M}_{2}$ & 699 & 15 & 34 & 748 \\
\hline $\mathrm{M}_{3}$ & 11,842 & 490 & 1,296 & 13,628 \\
\hline $\mathrm{N}_{2}$ & 23,773 & 493 & 1,251 & 25,517 \\
\hline $\mathrm{N}_{3}$ & 48,465 & 706 & 1,973 & 51,144 \\
\hline
\end{tabular}




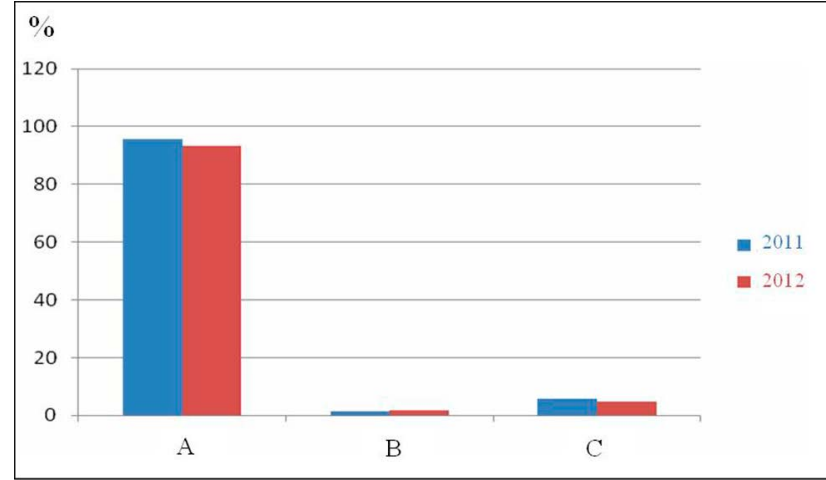

Figure 2 Proportion of qualified (A), temporarily qualified (B) and unqualified (C) vehicles of $\mathrm{N}_{2}$ category submitted to regular technical inspection in 2011 and 2012

Figure 2 shows that in 2011 the vehicles of $\mathrm{N}_{2}$ category were evaluated in regular technical inspection as follows: $95.60 \%$ were qualified, $1.47 \%$ was temporarily qualified, and $5.93 \%$ were unqualified. In 2012, the evaluation of the same vehicle category was as follows: $93.17 \%$ were qualified, $1.93 \%$ was temporarily qualified, and $4.90 \%$ were unqualified. Comparing various evaluations enabled the following conclusion: in the classification grade qualified, there was in 2012 a decrease by $2.43 \%$, the classification grade temporarily qualified showed an increase by $0.46 \%$, and the classification grade unqualified was characterised by a drop by $1.03 \%$ compared with 2011 .

It can be stated from the above-mentioned facts that increase was only in the classification grade temporarily qualified, which could be due to minor deficiencies on inspected vehicles. Minor deficiencies are considered deficiencies and failures occurred probably by ignoring the maintenance of this vehicle category.

\section{Technical condition evaluation results for $\mathrm{M}_{3}$ and $\mathrm{N}_{3}$ categories}

The data from Tables 1 and 2 were used to determine the proportion of vehicles of $\mathrm{M}_{3}$ and $\mathrm{N}_{3}$ category evaluated in the technical inspection of 2011 and 2012 as qualified, temporarily qualified and unqualified. The data are recorded in Table 4. The proportion of vehicles in individual evaluations was calculated using Equation (1) (Hrubec, 2001) and rounded to two decimal places.

Table 4 Proportion of qualified, unqualified and temporarily qualified vehicles of $\mathrm{M}_{3}$ and $\mathrm{N}_{3}$ category submitted to regular technical inspection in 2011 and 2012

\begin{tabular}{|l||c|c|c|c|}
\hline \multirow{2}{*}{ Year } & \multirow{2}{*}{ Category } & \multicolumn{3}{|c|}{ Qualification in \% } \\
\cline { 3 - 5 } & & qualified & $\begin{array}{c}\text { temporarily } \\
\text { qualified }\end{array}$ & unqualified \\
\hline \hline 2011 & $\mathrm{M}_{3}$ & 82.20 & 4.11 & 13.69 \\
\hline & $\mathrm{N}_{3}$ & 94.29 & 1.11 & 4.60 \\
\hline 2012 & $\mathrm{M}_{3}$ & 86.89 & 3.60 & 9.51 \\
\hline & $\mathrm{N}_{3}$ & 94.76 & 1.38 & 3.86 \\
\hline
\end{tabular}

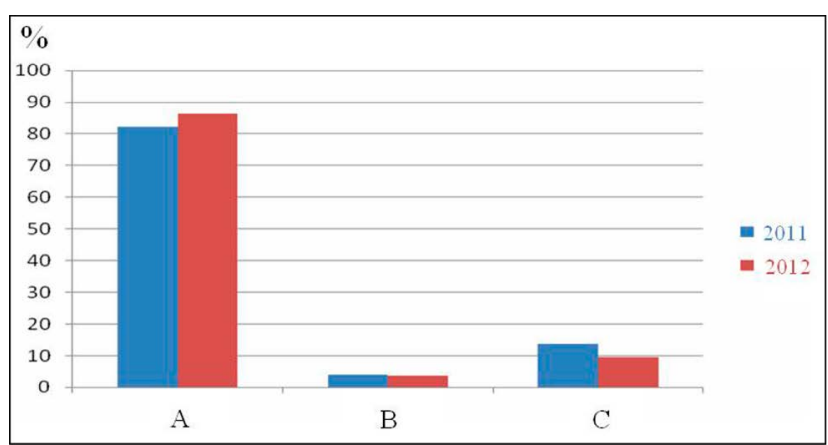

Figure 3 Proportion of qualified (A), temporarily qualified (B) and unqualified (C) vehicles of $M_{3}$ category submitted to regular technical inspection in 2011 and 2012

Figure 3 clearly shows that in 2011 there were $82.20 \%$ of $\mathrm{M}_{3}$ category vehicles classified as qualified, $4.11 \%$ temporarily qualified and $13.69 \%$ unqualified. In 2012, the situation was somewhat different; the category qualified represented $86.89 \%$, temporarily qualified $3.60 \%$ and unqualified $9.51 \%$. By comparing the individual evaluations during the reporting period, it was found that in 2012 there was an increase by $4.69 \%$ in the classification grade qualified, a decrease by $0.51 \%$ in the classification grade temporarily qualified, and a decrease by $4.18 \%$ in the classification grade unqualified compared with 2011.

It is obvious that the technical qualification of vehicles in this category was significantly improved, which could be due to a variation of the vehicle fleet, e.g. by introducing a requirement that $M_{3}$ vehicles older than eight years are required to undergo the regular technical inspection in halfyear periods, as well as by improving vehicle maintenance schedules, etc.

It can be determined from Figure 4 that based on the regular technical inspection of vehicles of $\mathrm{N}_{3}$ category in $2011,94.29 \%$ of vehicles were evaluated as qualified, $1.11 \%$ as temporarily qualified, and $4.60 \%$ as unqualified for road traffic. In 2012, there was a slight change, and according to our findings, $94.76 \%$ of vehicles were qualified, $1.38 \%$ was temporarily qualified, and $3.86 \%$ were unqualified. Comparing the results from 2012 with the results from 2011 enabled the following conclusion: there was an increase by $0.47 \%$ in the classification grade qualified in 2012 , an

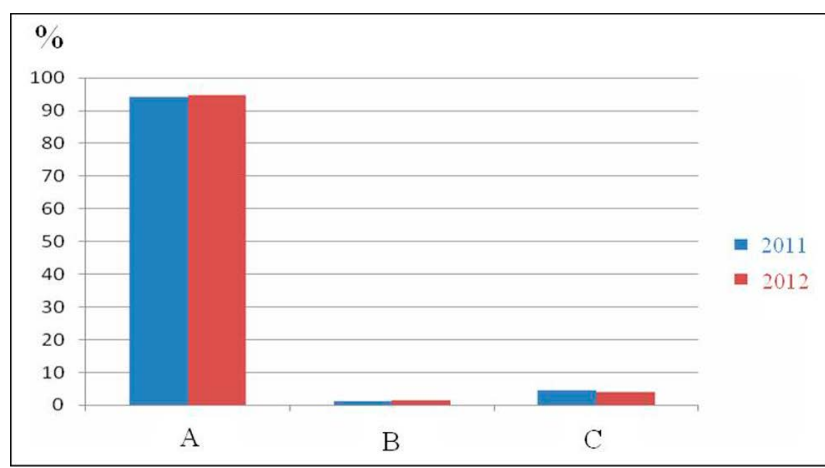

Figure 4 Proportion of qualified $(A)$, temporarily qualified (B) and unqualified (C) vehicles of $\mathrm{N}_{3}$ category submitted to regular technical inspection in 2011 and 2012 
increase by $0.27 \%$ for temporarily qualified vehicles, and a decrease by $0.74 \%$ for unqualified vehicles compared with 2011.

Comparing the results for the $\mathrm{N}_{3}$ category, it is possible to state that in 2012 there was an increase in qualified and temporarily qualified vehicles, which can be caused by a variation of the vehicle fleet, e.g. due to the introduction of a toll system, in which the amount of payments depends on the emission class of vehicles.

\section{Conclusion}

This paper deals with the evaluation of vehicles of $M_{2}, M_{3}$ and $\mathrm{N}_{2}, \mathrm{~N}_{3}$ category on the basis of results obtained at the technical inspection and emission control station between 2011 and 2012. Almost in all categories of vehicles, there was observed an increase in the evaluation of vehicles as qualified for road traffic during the reporting period, except for the $M_{2}$ and $N_{2}$ category, which revealed a drop in this evaluation. The highest increase for the reporting period was found in the $M_{3}$ category. The highest increase for temporarily qualified vehicles was recorded in the $\mathrm{N}_{2}$ category and decline in all the other categories (the highest fall for the $M_{3}$ category). For unqualified vehicles, the highest increase was reported in the $M_{2}$ category, and other categories showed a decline in this evaluation during the reporting period. The greatest decrease for the reporting period occurred in the $M_{3}$ category.

All of the categories in the reporting period exceeded the evaluation limit above $90 \%$, except for vehicles of $M_{3}$ category. It is the case of vehicles for mass transport of passengers, while they have not a comparable technical qualification with other vehicle categories, and therefore they do not reach the qualification limit comparable with other vehicle categories. Based on the above-mentioned facts, it can be stated that the technical condition of vehicles is gradually improving, which is supported by observations from roadworthiness tests.

\section{Acknowledgement}

Supported by the project VEGA No 1/0519/13 'Solution of changes to the technical and exploitative features of mobile energetic sources in terms of using different fuels, their effective use with monitoring of selected technical, energetic, environmental and emission parameters'.

Supported by the Ministry of Education of the Slovak Republic, project VEGA No 1/0857/12 'Reduction of unfavourable impacts of agricultural and transport machinery on environment'

\section{References}

HRUBEC, J. 2001. Riadenie kvality. Nitra : SPU, 203 s. ISBN 80-7137-849-6.

KRÁLIK, M. - JABLONICKÝ, J. - KOSIBA, J. - HUJO, L.. - ANGELOVIČ, $M .2012$. The effect of hydrogen on diesel engine smoke emission. In Machines, Technologies, Materials, vol. 6, 2012, no. 6, pp. 23-25. ISSN 1313-0226.

MÜLLEROVÁ, D. - JABLONICKÝ, J. - HUJO, L'. - TKÁČ, Z. - KUČERA, M. - KOSIBA, J. 2012. Measurement of operating parameters and emissions of tractor with diesel oil and biofuel. In TEAM. Osijek-Baranja : Josip Juraj Strossmayer University, vol. 4, 2012, no. 1, pp. 299-302. ISSN 1847-9065.

JABLONICKÝ, J. - TKÁČ, Z. - MAJDAN, R. - MÜLLEROVÁ, D. - HUJO, L'. - VOZÁROVÁ, V. 2012. Hodnotenie vlastností biopalív a biomazív. 1. vyd. Nitra : SPU, 143 s. ISBN 978-80-552-0766-7.

ŠTEFINA, M. - MAJDAN, R. 2012. Hodnotenie prevádzky vozidiel využívajúcich palivo CNG. In Recent Advances in Agriculture, Mechanical Engineering and Waste Policy : international scientific students conference. Nitra, April 25, 2012, Slovakia (249). ISBN 978-80-552-0781-0.

SZABÓ, M. - MAJDAN, R. 2012. Využitie informačných systémov automobilovej dopravy v praxi. In Recent Advances in Agriculture, Mechanical Engineering and Waste Policy : international scientific students conference. Nitra, April 25, 2012, Slovakia (249). ISBN 978-80-552-0781-0.

Zákon č. 725/2004 Z. z. Národnej rady Slovenskej republiky z 2. decembra 2004 o podmienkach prevádzky vozidiel v premávke na pozemných komunikáciách a o zmene a doplnení niektorých zákonov. Vyhláška č. 578/2006 Z. z. Ministerstva dopravy, pôšt a telekomunikácií Slovenskej republiky z 12. októbra 2006, ktorou sa ustanovujú podrobnosti o niektorých ustanoveniach zákona č. 725/2004 Z. z. o podmienkach prevádzky vozidiel v premávke na pozemných komunikáciách a o zmene a doplnení niektorých zákonov v znení neskorších predpisov.

\section{Contact address:}

Ing. Jozef Švec, Slovak University of Agriculture in Nitra, Faculty of Engineering, Department of Transport and Handling, Tr. Andreja Hlinku 2, 94976 Nitra, Slovakia, 苗 +421 (37) 64145 37, e-mail: jozef.svec@uniag.sk 